Article

\title{
A European (German) View on Comparative Theology: Dialogue with My Own Past
}

\author{
Ulrich Dehn \\ Chair of Missiology, Ecumenics, and Religious Studies, Department of Protestant Theology, Faculty \\ of the Humanities, Hamburg University, Sedanstr. 19, D-20146 Hamburg, Germany; \\ E-Mail: ulrich.dehn@uni-hamburg.de; Tel.: +49-40-42838-3776
}

Received: 1 September 2012; in revised form: 5 November 2012 / Accepted: 12 November 2012 / Published: 14 November 2012

\begin{abstract}
For the last couple of years, particularly after the publication of the (German) book "Comparative Theology" by Bernhold Reinhardt and Klaus von Stosch, there was a significant attentiveness of this subject amongst German scholars. For many, it was the long anticipated antithesis/alternative to the pluralist theology of religions, even if it had not been devised explicitly to serve as such an alternative. For others, it has been an appropriate way to express their desire for a substantial interreligious dialogue in a theologically responsible way. This paper tries to review some of the major German contributions (being read alongside international ones) and reactions to Comparative Theology and to search for the motive behind its sudden popularity in some circles. It will also try to reconstruct the possibilities for Comparative Theology within the wider setting of the process and development of religious traditions as they grow and change in never-ending interaction and communication within the history of religions, ideas and society.
\end{abstract}

Keywords: comparative theology; theology of religions; history of religions; truth claim; heterogeneity; inter-religious dialogue

\section{Introduction}

The title of my paper ${ }^{1}$ suggests that there is a particular perception of comparative theology in Germany, but this may not be the case. It remains to be seen whether the German discussion adds

1 At this point I would like to heartfully thank John H. Berthrong and Francis X. Clooney for their extremely helpful comments to my essay. I learnt a lot from their ideas, and from this culture of scholarly sharing (quite different from the German way). 
aspects to the general debate that has been intensifying for around the last 10 years but has had forerunners for some decades. I use 'forerunners' in the sense that comparative theology offers and formulates a model of doing inter-religious research and dialogue which may be found in many activities as early as in medieval times - even Nicolaus of Cues' Cribratio alkorani (1460/61) may be counted here as he is doing comparative research about the Quran from a Christian perspective, even though he did not do this from a dialogical, but rather a polemical perspective. The polemical outlook was true for most medieval theologians due to a lack of knowledge of the other religions, their holy scriptures, their rites and their background, in general. 'Comparison' and 'dialogue' were the modes and methods to convince the public of the irrationality of the other religion and to prove the truth of the Christian dogma. This was the case with Petrus Abaelard (12th century), Ramon Lull (13th century), and for Martin Luther knowledge of the Quran was helpful in order to know more about the enemy. A turn of religious thinking started only at the end of the 18th and the beginning of 19th century when Enlightenment thinking and European language translations of scriptures were in reach and the general climate started to change towards a discovery of peaceful potentials of religions and mutual tolerance [1]. The term itself came in to use in the 19th century, at that time in contrast to 'theoretical' theology, or indicating the study of religious doctrines ([2], p. 521). Already in 1699, James Garden used the term 'theologia comparativa' in distinction from an absolute theology. ${ }^{2}$

In my paper I will try to think about a couple of questions and problems regarding comparative theology, including the concepts and answers that have been offered in my research so far. This will include some simplifications as the conceptual offers are so widespread and different from each other that one may hardly believe that they fit under the one umbrella of 'comparative theology'. Giving the title 'European' or 'German' I do not mean to work only with references from this part of the world. Rather I will present my views which — whether I like it or not—probably are very German, but I will refer to all contributions known to me and relevant to my judgment.

Let me first of all try to summarize some of the claims of C.T. being raised, although they are not necessarily all shared by all C.T. representatives and some major issues which shall be treated in this paper.

- Some advocates of C.T. (e.g., Klaus von Stosch) claim to bypass the 'dilemma' of a theology of religions by asserting that it does not need one but to construct the hermeneutics and framework of inter-religious interaction in the process of doing dialogical work. It remains to be analyzed whether C.T. is really a 'theoretical virgin' and is able to start dialogue and comparisons in a theoretical vacuum.

- Within the German discussion about a confessional and theological way of doing dialogue of religions, on one side, and doing research about religions using empirical and sociological methods without adhering to a particular faith on the other, C.T. is considered a theological method with a confessional position, a claim which would put it in a contradictory position with the theologies of religion. It remains to be seen whether in scholarly hermeneutics there is such a thing as the distinction of theological and empirical methods with regard to religions and, if so, on which side we would find the C.T.

- Within the many variations of C.T., what are the marking points which are common to them? What is the core of C.T.?

2 I thank Francis Clooney for this hint. 
- The major antagonist to C.T., besides a secular study of religion and the quest for a 'pure' and non-comparative Christian theology, seems to be the pluralist theology of religions, particularly its most prominent exponent John Hick and his most outspoken follower Perry Schmidt-Leukel. What are the main points in favor of agreement, where can they be reconciled, where are the everlasting differences, if any?

- What purpose does C.T. serve beyond that which dialogical research has previously served for a long time? What is the surplus of saying 'comparative' instead of 'dialogical'?

This last section will offer some conceptional ideas about C.T. and its function within the history of religions.

\section{C.T. and the Theology of Religions}

In order to clarify the relation of C.T. to the field of a theology of religions and whether it is a substitute for it or renders it obsolete, there needs to be clarity about what the purpose of the theology of religions is. According to various authors (e.g., Perry Schmidt-Leukel, Reinhold Bernhardt, Klaus v. Stosch), a theology of religions tries to give an idea about how one religious system, in our case Christian faith, can define its relation to other religions and at the same time has its self-reflection and continuous self-reconstruction encouraged by the encounter with other religions. The details of a theology of religions give criteria about whether another religion is to be considered inferior to my own faith, of equal spiritual rights or including elements which may be identified as being similar to my own tradition. Some religious traditions have the privilege, due to their age, to look back on older religions and define their basis in relation to their holy scriptures, such as Islam (looking back on, e.g., Judaism and Christianity) and Baha'i, considering themselves as the crown of the history of religion. Others, like Christianity, need a posteriori theological constructions to put themselves into an innovative and dialogical theological relationship if ever they think it necessary. This type of theological activity has two components, as is pinpointed by v. Stosch and others: On one hand, it tries to support the reality of a coexistence and plurality of religions which cannot but interact with each other respectfully, on the other, it needs to take account of the unbroken affirmation of my faith's truth and the central position of Jesus Christ which poses a challenge to the way I look at other religions equally claiming to hold the truth. Whether these two components can coexist in a theologically responsible way or will exclude each other and become an impasse (as v. Stosch thinks) needs to be discussed. I suggest making use of the idea that my personal affirmation of my faith as the truth which is the one relevant aspect for me (and my faith community) (as the inter-subjective 'absoluteness' of Christian truth) does not exclude the intellectual and mental recognition that there exist other religious traditions and truth claims in their own right and dignity and harboring their own inter-subjective truth and possibly being in contrast to particular contents of my tradition (such as the crucifixion of Jesus Christ being denied by Quran sura 4,157-159 and again being interpreted differently by the Ahmadiyya community - both versions have their reasonable position in the history of interreligious interaction $^{3}$ ). Following this argumentation there should not be a substantial incompatibility of 'my

Klaus von Stosch in his writings frequently mentions the negation of Jesus' death on the cross in the Quran as one point not acceptable by the Christian partner in the process of a C.T. (e.g., [3], p. 32). This seems to me a big challenge to v. Stosch's concept of truth and to the dialogue competence of his idea of C.T. If a C.T. fails to constructively handle an 
truth' and the acceptance of the truth of the other as they do represent a truth which is true in an inter-subjective sense and is the authentic truth for each single person and community. Here I like to borrow from the pragmatic truth concept of Charles S. Peirce being further elaborated by William James and John Dewey [4,5], as I suppose that a Ptolemaic idea of truth would not carry me far in inter-religious interaction and comparative studies. Nevertheless, this is a modification on a purely pragmatic idea of truth which would only stress its viability and its competence to be valuable for the life of truth-holders. It needs to be added that internal criteria like authenticity and faithfulness within one's own religion and the recognizability of one person adhering to a particular religious tradition should be part of accepting truth claims. Anyway, this clarification has only a limited function in considering whether a theology of religions should be there and where the place of C.T. might be. Nevertheless it makes me aware that truth is, on one hand, not an arbitrary issue of an every day new option, and on the other hand should not support exclusivistic standpoints.

To add one more thought: I make use of the terminology of truth-holders or believers and do this for one particular reason. Trying to find out something about the truth claims of 'religions' implies that one essentialises religions as monolithic entities without taking into account that they change, that a 'religion' can be identified, apart from the scriptures and other written traditions and architectural monuments, only in the life of the believers, in their rituals, in the communication of religious humans and communities. Any 'religion' is a mosaic piece of art changing its parts by every single step through history. A theology of religions, be it exclusivistic, inclusivistic, or pluralistic, necessarily finds itself trapped in the presupposition to handle fixed religious compounds and clarify their relation to each other, knowing that even within one such 'compound' there are elements being stressed in a different way by different denominations within one 'religion'. For example, the dogma of the trinity, a major element in Orthodox thinking, or, in contrast, Jesus' suffering and death on the cross as the center of most Protestant orientations, or, in Islam, Ali being a major factor in Shiite Islam which he is not in Sunnite Islam etc. I do not stress the logical incompatibility of doctrinal elements but try to think of a procedure to interact, comparing each other without sticking to whole religious systems but looking for a case-by-case means of communicative hermeneutics. The above-described essentialisation of religion is what I consider the real impasse of a theology of religions, at least of most types I came across, and probably of most ways to think about religions. Being considered this way, a procedure according to C.T. should be able to celebrate religious diversity instead of being irritated by it and be hesitant to stick to a particular construction of religious relationship as a theology of religions would support. ${ }^{4}$ In this regard even the suggestion to let the 'Abrahamic religions' (Judaism, Christianity, Islam) have a dialogue with each other sounds rather essentialising-and exclusive to those who might also like to be members of the club but do not have a focus on the Abraham tradition. In order to say it concisely: In a very broad sense, C.T., as I like to propose it, may

issue like this — theological differences focusing on one common point—without hurting the dialogue partners, it is not worth the name.

4 At this point, Perry Schmidt-Leukel needs to be contradicted as he writes: “... my bad news for Fredericks and his German followers is that 'comparative theology' will not lead out of the impasse of theology of religions but straight into it. The liberating good news, however, is that the theology of religions is not an impasse at all' ([6], p. 91). C.T., as I understand it, may very well be able to avoid any type of theology of religions and still be able to respond to the questions which a theology of religions is confronting — which Schmidt-Leukel doubts ([6], p. 91). 
be within the range of theology of religions, but as a type sui generis which will find its communicative place and structure case by case in the world of religious heterogeneity and not within the setting of exclusivism, inclusivism and pluralism.

This is the one dimension of C.T. that might as well be part of the general idea of interreligious dialogue. The other stage is to consider within my own dialoguing tradition what there is to be learnt from the partner in dialogue about our particular subject of comparative communication if ever the dialogue should go beyond what might be called comparative religion, respectively a purely phenomenological comparison, such as Schmidt-Leukel stresses ([6], p. 102). In what regards may transformations of my position be challenged? What does it mean to be a Christian theologian vis-à-vis other religious outlooks? In the process of reconsidering elements of the interaction and the impact they may have in form of a revision of my religious position, it is necessary for criteria to judge the gravity of challenges which poses the procedure close to the realm of a theology of religions. However, the criteria need to be generated out of the comparative process, not be transported by a preceding theological system of interreligious relations. ${ }^{5}$

\section{Major Arguments towards Comparative Theology in German Speaking Theology}

Christian Danz, a systematic theologian at Vienna University, in his introduction to the theology of religions [7] appreciatively summarizes major aspects of C.T. as an attempt to avoid the bird's eye view on religion(s). Instead he perceives their differences and renounces the concept of a 'common core' of religions. Danz notices C.T.'s attention to concrete issues between two religious traditions instead of performing global comparisons and using general concepts including side-stepping of ready-made theologies of religions. He also honors the conceptual intention of C.T. to evaluate a religion resp. elements of it only after having encountered it in the comparative process and to have it as a mirror for reflecting one's own tradition ([7], pp. 104-106). However, it is the latter point which Danz doubts: Will C.T. really be able to renounce the use of general concepts? Will it not at the end of the comparative process, when the moment of judgements has come, have to make use precisely of those concepts which it has at the beginning of the process denied to take into account? He claims that a C.T. will have to get back to general concepts if it does not want to resort to an 'intransparent empirism' ([7], pp. 106-107). Danz' criticism of C.T. is close to that of Schmidt-Leukel and has in common with him as well with v. Stosch that a hiatus between theological hermeneutics and 'empirism' resp. the 'purely' phenomenological comparison is asserted. This issue, a gap between theological hermeneutics and phenomenological comparison, we have to discuss later.

Schmidt-Leukel claims: „And if the comparatist starts her work from a specific religious or confessional tradition, it is doubtless the case that she, as part of her own religious background, will already be influenced by those religious convictions that have their own implications on the truth claims entailed in the beliefs of others. To bracket or exclude the implications of one's own religious presuppositions would once again mean to fall back into the business of a purely phenomenological comparison - and apart from that, there are good reasons to doubt whether such a bracketing is possible at all." ([6], p. 102) Schmidt-Leukel is true in his supposition that there is no hermeneutical process without a 'package' of influences and impregnations which influence our perspective on texts and other objects of understanding. This is true and trivial at the same time, as all our perceptions bear the marks of our constructions. 
Friedmann Eissler $^{6}$ deals with the question whether C.T. may serve as an alternative to known theologies of religions. He introduces the thought of Clooney, Fredericks and v. Stosch and expresses appreciation of some of their major concerns, like the major impasse of all previous concepts of theology of religions, as v. Stosch has it, of the acceptance and appreciation of religious plurality on one hand, and the truth claim of one's own religion, on the other ([8], pp. 451-452). He doubts that if one is faithful to the truth claim of one's own religion (Christianity) whether there is a way to the acceptance of other truth claims - without converting to the other religion. Eissler demands a position which sticks to the Christian basics of faith (Bible, confessions) and upholds the claim to be true for all humankind. Citing Norbert Hintersteiner, who writes that C.T. 'implicates and asks for' an 'inter-religious community' no longer sticking to the faith of one particular community and its theological discourse ${ }^{7}$, he feels that this bird's eye perspective may not be appropriate for religions coming into the horizon of comparison. Eissler's position, which includes a very narrow truth concept, leaves only a small space for constructive interreligious comparison, mutual appreciation and dialogue as it first of all stresses the apologetic and missionary part of interaction and does not even explicitly appreciate the chances of C.T. within a religiously plural world, as Danz does. For some authors, C.T. seems to offer a way to escape the pluralist option even if they did not look closely at the intentions and concepts of C.T.

Juergen Werbick of Muenster University, a supporter of C.T., perceives that there should be a way to overcome the militant competitiveness of religions and instead find out what might make them partners and mutually discover not weaknesses but strong points as in certain concerns it will be the same challenges to be confronted, and thus a common interest to have the others as strong companions. The challenges, according to Werbick, are of human and social character, they concern human basic experiences and quests. In the comparative process we can discover how the others handle challenges, the specifics of one's own way of handling it, and learn from the ways others meet the challenges and judge and re-view our own way in relation to others. This does, as Werbick stresses, not automatically mean appreciating other ways uncritically but can result in critical evaluation. One possible outcome may be to discover our own religious tradition as the religious and cognitively superior one, but Werbick's major point is that militant competition is overruled and embraced by appreciating and honoring argumentation. This task has, according to Werbick, a dimension of common human and religious interest ([10], pp. 188-190).

\section{Comparative Theology in the Context of the History of Religions}

Beyond struggles with the truth problem and the issues of inclusiveness, acceptance and coherence, C.T. with its methods of comparison, dialogue, appreciation and evaluation opens a process of historical recapitulation. Religions, as indicated above, do not fall from heaven like monoliths and stay

6 Eissler is working with the Protestant Institute for Religions and World Views (EZW, Berlin) of the Protestant Church in Germany (EKD).

7 Quoted in [8], p. 454, from [9], p. 337. This idea of Hintersteiner seems unusual to me within the range of C.T. Christine Tietz who quotes Hintersteiner in her contribution 'Dialogkonzepte in der Komparativen Theologie' ([9], pp. 315-338) also does not feel comfortable with this position which overcharges the idea of C.T. and raises the threshold for participation. 
unchanged journeying through history. They start with people who feel an impasse with their religious environment and pick up a new reforming idea which comes into a forming process. The people transporting it encounter other ideas and start to walk a long way of formation, adaptation, stabilization, new encounters and challenges, establishing a community with rules and rituals, formulating a confessional code which defines who will or will not be one of them. Narratives are formed, myths which mark the ideas and stories to be important for the identity of the new group of believers. A religious movement is like a ball of clay which is thrown, collides, changes its form with every single collision and makes other loam balls change as well by meeting and 'communicating'. Such was the case when Buddhism met the world of the rural Hindu gods: reincarnation ideas of old Brahmanism, and, centuries, later the godhead families of East Asian pre-Buddhist religious worlds, influenced Hinduism and Buddhist ideas changed in themselves. In Japan it was the mutual penetration and re-figuration of Shinto and Buddhism which created new religious amalgams, the same being true for the Tibetan confluence of Indian Buddhism, Tantrism, Bon traditions and Chinese spiritual worlds [11,12].

This process is a never-ending one, only becoming slower and viscous because of institutionalization, competitive identity struggles and power games. The dialogical part of C.T. is a chance to reconstruct this movement and process and generate a new understanding of religious formation processes. It opens the horizon of various responses to the questions and challenges of humankind and life - in this regard I feel close to Werbick - and may develop to be a 'communicative theology' in the quest for new hermeneutics of religious processes. This quest first of all is a clarification process about how my religious tradition became what it is and who its mothers, fathers, sisters, brothers and other relatives are. It does not touch the truth issue in this stage as this is a cognitive search for the elements out of which truth shall be generated. Of course, beyond clarification, C.T. or communicative theology implicates the challenge whether it is a follow-up to historical clarifications or whether there is a need and an intuitive urge to be a different theology in the long run of the process of comparison and communication. Facing this question it comes to the point whether C.T. should be an intellectual game, a matter of historical reconstruction or a process of existential seriousness. I opt for the second one with elements of the third. Klaus von Stosch's claim of C.T. as 'main task of the theology of the future' being explicated in a complete reshuffle of theological faculties, e.g., establishing chairs for theologies other than Christian, having the challenge of the other religion(s) as a permanent background for theological reflection ([3], pp. 317-322, [9], pp. 29-31), sounds radical but to a large extent describes projects already on the move and being practiced in dialogically oriented inter-religious research and the way many theological suggestions for the last years have been considering the horizon of other religions $[13,14] .{ }^{8}$ Many of them did not seek the setting of a C.T. but might be judged as monological dialogues. Anyway they were aware that Christian theology can no longer be reflected in splendid isolation and is challenged for encounter by 'theologies' in other religions.

Making my last point, I doubt the validity of distinguishing an internal and an external view of religions in the scholarly process of C.T. Internal views may, beyond the 'facts', have a confessional and affectional aspect, but the 'facts' and the 'material' should be the same as with the external viewotherwise one of them is right and the other wrong. In any case it should be a good practice in teaching,

Also see the government support for establishment of chairs of Islamic theology and training of teachers for Islamic lessons. 
learning and having dialogue to have adherents of a religion speak for their tradition instead of having Christians talk about Islam or Buddhism or the other way round. The results should be authentic communicative situations and an equal standing and representation of religious communities at universities (as has been the dream of f.e. Wilfred Cantwell Smith). However, there is no epistemological need to do this in order to have the 'correct views'.

C.T. will have the never-ending task of allowing humans of the different religious traditions search together for the answers to urgent questions of life and humankind. For this project which on different scales is underway in many places already, a fitting and congenial design at universities-particularly in Germany-is still a great need. One implication might be the establishment of multi-religious theological faculties which offer connections between the religions and for the flow of new ideas and mirror the religiously plural situation of the country. ${ }^{9}$

\section{Reference}

1. Rainer Forst. Toleranz im Konflikt. Frankfurt am Main: Suhrkamp, 2003.

2. Francis X. Clooney. "Comparative Theology: A Review of Recent Books (1989-95)." Theological Studies 56, (1995): 521-550. http://www.bc.edu/schools/cas/theology/comparative/ resources/articles/theolstudies.htm.

3. Klaus von Stosch. Komparative Theologie als Wegweiser in der Welt der Religionen. Paderborn: Schoeningh, 2012.

4. William James. The Meaning of Truth-A Sequel to ,Pragmatism: New York/London: Longmans, Green \& Co, 1909.

5. Charles Hartshorne, Paul Weiss, and Arthur W. Burks, eds. "Pragmatism and Pragmaticism." 58th ed. Collected Papers of Charles Sanders Peirce. Bristol: Thoemmes u. a., 1998, Vol. 5.

6. Perry Schmidt-Leukel. "Comparative Theology: Limits and Prospects." In Transformation by Integration. London: SCM Press, 2009, 90-104.

7. Christian Danz. Einfuehrung in die Theologie der Religionen. Wien: LIT, 2005.

8. Friedmann Eissler. "Komparative Theologie.” Materialdienst der EZW 74 (2011): 449-455.

9. Reinhold Bernhardt, and Klaus von Stosch, eds. Komparative Theologie. Zuerich: Theologischer Verlag, 2009.

10. Juergen Werbick. Vergewisserungen im interreligioesen Feld. Muenster: LIT, 2011.

11. Kenji Matsuo. A History of Japanese Buddhism. Folkstone: Global Oriental, 2007.

12. Michael L. Walter. Buddhism and Empire: The Political and Religious Culture of Early Tibet. Leiden: Brill, 2009.

13. Hans-Martin Barth. Dogmatik: Evangelischer Glaube im Kontext der Weltreligionen. Guetersloh: Guetersloher Verlagshaus, 2001

14. Hans Waldenfels. Kontextuelle Fundamentaltheologie, 2nd ed. Paderborn: Schoeningh, 1988.

15. Ulrich Dehn. Religionswissenschaft als theologische Disziplin? In Religionsdifferenzen und Religionsdialoge (= EZW-Texte No. 210), edited by Reinhard Hempelmann. Berlin: EZW, 2010, 90-100.

\footnotetext{
${ }^{9}$ For ideas in this context see also [15].
} 


\section{Selected Bibliographies Relevant to C.T.}

Francis X. Clooney. Theology after Vedanta: An Experiment in Comparative Theology. Albany/New York: Orbis Books, 1996.

Francis X. Clooney. The New Comparative Theology: Interreligious Insights from the Next Generation. London: T\&T Clark, 2010.

James L. Fredericks. “A Universal Religious Experience: Comparative Theology as an Alternative to a Theology of Religions.” Horizons 22 (1995): 67-87.

Norbert Hintersteiner. Traditionen überschreiten: Angloamerikanische Beiträge zur interkulturellen Traditionshermeneutik. Wien: Universitätsverlag, 2001.

Norbert Hintersteiner. "Dialog der Religionen.” In Handbuch Religionswissenschaft, edited by Johann Figl. Innsbruck/Goettingen: Tyrolia/Vandenhoeck \& Ruprecht, 2003, 834-852.

Perry Schmidt-Leukel. Gott ohne Grenzen. Guetersloh: Guetersloher Verlagshaus, 2005.

Ulrich Dehn. "Einleitung: Brauchen wir fuer den interreligioesen Dialog eine Theologie der Religionen?" In Handbuch Dialog der Religionen, edited by U. Dehn. Frankfurt am Main: Lembeck, 2008, 13-27.

Wikipedia. "Komparative Theologie." http://de.wikipedia.org/wiki/Komparative_Theologie (accessed on 25 July 2012).

Wikipedia. "Comparative theology." http://en.wikipedia.org/wiki/Comparative_theology (accessed on 25 July 2012).

http://www.facebook.com/pages/Comparative-theology/112127335473352 (accessed on 25 July 2012).

ZeKK. http://kw.uni-paderborn.de/institute-einrichtungen/zekk (accessed on 1 August 2012).

(C) 2012 by the author; licensee MDPI, Basel, Switzerland. This article is an open access article distributed under the terms and conditions of the Creative Commons Attribution license (http://creativecommons.org/licenses/by/3.0/). 